\title{
ANALISIS JENIS KELAMIN DAN KEBIASAAN JAJAN DENGAN KEJADIAN ISPA PADA ANAK DI TK DHARMA WANITA PERSATUAN UNIT SIDOKLUMPUK SIDOARJO
}

\author{
Firdaus *Riska Anindia Putri ** \\ Fakultas Keperawatan dan Kebidanan \\ Universitas Nahdlatul Ulama Surabaya Jl. Smea 57 Surabaya \\ e-mail: firdaus@ unusa.ac.id
}

\begin{abstract}
Many snacks are less qualified of health so they threaten children's health. This condition reflects the children become accustomed to eating bad snacks in the school environment. The purpose of this study was to determine the sex and the habit of eating snacks with upper respiratory tract infection occurrence on children in Dharma Wanita Persatuan Unit Kindergarten, Sidoklumpuk, Sidoarjo. The design of the study used an analytic-cross sectional approach. The population was the entire students in Dharma Wanita Persatuan Unit Kindergarten, Sidoklumpuk, Sidoarjo as 28 students, the sample which was 26 respondents was taken by using a simple random sampling technique. The independent variable was sex, snacks habit and the dependent variable was the occurrence of upper respiratory tract infection. The instruments used checklist and questionnaire. The data were analyzed by using spearmen rank test with a significance level $(\alpha=0,05)$. The result of the study was the majority of the respondents $(57.7 \%)$ was female and the majority of the respondents $(53.8 \%)$ had a habit of eating bad snacks and almost half of the respondents $(46.2 \%)$ was rare occurrence of URTI. Spearman Rank test result obtained that $\rho=0,020$, there was no correlation of sex with the upper respiratory tract infection occurrence in Dharma Wanita Persatuan Unit Kindergarten, Sidoklumpuk, Sidoarjo. Furthermore, it was obtained that 0,010 meant that there was correlation between the habit of eating snacks and the occurrence of URTI in Dharma Wanita Persatuan Kindergarten, Sidoklumpuk, Sidoarjo. The conclusion of the study was females most often consume foods which have striking colors, attractive appearances, sweet and savory flavors that are around the school so they will occur URTI. It is advised that parents encourage their children not to buy snacks and make the children become accustomed to having breakfast first.
\end{abstract}

Abstrak : Banyak jajanan yang kurang memenuhi syarat kesehatan sehingga mengancam kesehatan anak. Kondisi ini mencerminkan anak menjadi terbiasa mengkonsumsi jajan yang buruk di lingkungan sekolah. Tujuan penelitian ini adalah mengetahui jenis kelamin dan kebiasaan jajan dengan kejadian ISPA pada anak di TK Dharma Wanita Persatuan Unit Sidoklumpuk Sidoarjo.

Desain penelitian analitik, menggunakan pendekatan cross sectional. Populasi seluruh siswa di TK Dharma Wanita Persatuan Unit Sidoklumpuk Sidoarjo sebanyak 28 siswa, besar sampel adalah 26 responden dengan teknik simple random sampling. Variabel independen jenis kelamin, kebiasaan jajan dan variabel dependen terjadinya ISPA. Instrumen menggunakan check list dan kuesioner. Analisis data menggunakan uji Spearman Rank dengan tingkat kemaknaan $(\alpha=0,05)$. Hasi lpenelitian sebagian besar $(57,7 \%)$ berjenis kelamin perempuan dan sebagian besar $(53,8 \%)$ memiliki kebiasaan jajan yang kurang baik dan hampir sebagian $(46,2 \%)$ jarang terjadinya ISPA. Hasil uji Spearman Rank didapatkan didapatkan $\rho=0,020$ ada hubungan jenis kelamin dengan terjadinya ISPA di TK Dharma Wanita Persatuan Sidoklumpuk Sidoarjo. Dan didapatkan 0,010 artinya ada hubungan kebiasaan jajan dengan terjadinya ISPA di TK Dharma Wanita Persatuan Sidoklumpuk Sidoarjo. Simpulan dari penelitian adalah jenis kelamin 
perempuan yang paling sering mengkonsumsi makanan dengan warna yang mencolok, penampilan yang menarik, rasa manis dan gurih yang ada di sekitar sekolah maka akan terjadi ISPA. Disarankan orang tua mendorong anaknya untuk tidak jajan sembarangan dan membiasakan anak sarapan dahulu.

Kata kunci: Kebiasaan jajan, Terjadinya ISPA

\section{PENDAHULUAN}

Banyak jajanan yang kurang memenuhi syarat kesehatan sehingga mengancam kesehatan anak.Ditemukannya kandungan zat berbahaya dalam jajanan anak yang dijual di sejumlah Sekolah Dasar .Kebiasaan anak sekolah untuk mengkonsumsi jajan yang ada di sekitar sekolah yang belum diketahui kebersihannya dapat berpengaruh terhadap kesehatan dan dapat menimbulkan suatu masalah kesehatan (Amourisva, 2014). Kebiasaan jajan juga merupakan bagian yang tidak terpisahkan dari kehidupan anak sekolah. Makanan jajan yang ditawarkan di lingkungan sekolah juga bermacam-macam seperti, gorengan, cireng, terang bulan, batagor, minuman bersoda. Jajanan tersebut dapat berisiko terhadap kesehatan disebabkan dari kontaminasi, tidak higienis, pembuatan jajan dengan peralatan yang kurang bersih, wadah dan cara penyimpanan yang tidak tepat, serta terpaparnya debu di sekitar lingkungan sekolah maka akan terjadi infeksi saluran pernafasan atas seperti demam, batuk, pilek, sakit tenggorokan.

Di dunia, prevalensi ISPA bagian atas menyentuh nilai rata-rata 25 juta pasien yang berkunjung ke tempat layanan pertama atau dokter umum. (WHO, 2012). Prevalensi ISPA di Indonesia berdasarkan diagnosis tenaga kesehatan dan keluhan penduduk adalah $25 \%$. Lima provinsi dengan ISPA yang tertinggi adalah Nusa Tenggara Timur $(28,3 \%)$, Papua $(31,1 \%)$, Aceh (30,0\%), Nusa Tenggara Barat $(28,3 \%)$ dan Jawa Timur $(28,3 \%)^{2}$. Berdasarkan profil dinas kesehatan kota Surabaya tahun 2014 Penyakit saluran pernafasan bagian atas menempati urutan pertama dari 10 penyakit terbanyak di Surabaya pada bulan Januari sampai bulan Mei 2014 dimana dalam statistik yang di keluarkan dinas kesehatan kota Surabaya penyakit saluran pernafasan atas mencapai (41\%) (Dinkes Surabaya, 2014). Berdasarkan data yang diperoleh dari sub bagian P2M Kabupaten Sidoarjo diperoleh informasi bahwa yang terkena ISPA terbanyak pada tahun 2015 adalah golongan umur 1 sampai 6 tahun yaitu 1.851 anak $(12 \%)$.

Dari hasil wawancara dengan guru, jumlah seluruh siswa adalah 28 siswa, yang tidak masuk sekolah dengan keterangan sakit pada bulan Januari sampai Februari berjumlah sekitar 15 siswa dan yang suka mengkonsumsi jajan yang di jual di lingkungan sekolah sekitar 18 siswa.

Penularan ISPA terjadi tanpa kontak dengan penderita maupun dengan benda terkontaminasi. Dari faktor lingkungan sekolah merupakan faktor yang paling dominan melalui makanan atau jajan. Anak-anak mengkonsumsi jajan di luar sekolah yang tidak sehat tersebut terdapat banyak kuman ataupun terkontaminasi virus yang menempel. Saat anak membeli jajan tersebut kuman atau virus ikut di makan oleh anak, kemudian virus masuk ke saluran pernafasan. Setelah itu virus mulai memperbanyak diri sampai akhirnya saluran pernafasan terinfeksi sehingga membuat hidung tersumbat, batuk, pilek, sakit tenggorokan.

Upaya untuk mengurangi makanan jajanan anak sekolah yang tidak sehat dan tidak aman perlu dilakukan usaha edukasi dan promosi kesehatan dari pihak tenaga kesehatan untuk melakukan penyuluhan. 
Peran serta dalam mengarahkan dan mengawasi terhadap kebiasaan jajan anaknya yang akan berpengaruh terhadap timbulnya penyakit ISPA (Infeksi Saluran Pernafasan Atas) yaitu dengan memberikan saran pada orang tua menganjurkan untuk membawakan bekal di sekolah atau makanan ringan yang bergizi, lalu bagi sekolah mungkin bisa menerapkan untuk cuci tangan sebelum ataupun sesudah makan dan kantin sekolah bisa menyediakan makanan yang baik untuk anak-anak. Hal ini dilakukan sebagai upaya untuk mencegah anak agar tidak jajan sembarangan.

\section{HASIL DAN PEMBAHASAN}

\section{a. Hasil .}

1. Hubungan jenis kelamin dengan kejadian ISPA

Tabel 1 Tabulasi silang hubungan jenis kelamin dengan terjadinya ISPA di TK Dharma Wanita Persatuan Sidoklumpuk Sidoarjo.

\begin{tabular}{ccccc}
\hline Jenis & \multicolumn{3}{c}{ Terjadinya ISPA } & $\begin{array}{c}\text { Jumlah } \\
\text { Kelamin }\end{array}$ \\
\cline { 2 - 4 } & $\begin{array}{c}\text { Tidak } \\
\text { pernah } \\
\mathrm{N}(\%)\end{array}$ & $\begin{array}{c}\text { Jarang } \\
\mathrm{N}(\%)\end{array}$ & $\begin{array}{c}\text { Sering } \\
\mathrm{N}(\%)\end{array}$ \\
& & & \\
\hline $\begin{array}{c}\text { Laki-laki } \\
\text { Perempua } \\
\mathrm{n}\end{array}$ & $0(60)$ & $6(55)$ & $\begin{array}{c}5(45) \\
5\end{array}$ & $11(100)$ \\
\hline Jumlah & $4(26,7)$ & $6(40)$ & $(33,3)$ & $15(100)$ \\
\hline & & $\begin{array}{c}12 \\
(46,2)\end{array}$ & $(38,5)$ & $26(100)$ \\
\hline
\end{tabular}

Berdasarkan tabel 1 menunjukkan bahwa dari 26 responden, terdapat 11 responden dengan kebiasaan jajan bajenis kelamin laki-laki sebagian besar $(55 \%)$ responden jarang terjadi ISPA, dari 15 responden dengan jenis kelamin perempuan hampir setengah $40 \%$ ) responden jarang terjadi ISPA

2. Hubungan kebiasaan jajan dengan terjadinya ISPA

Tabel 2. Tabulasi silang hubungan kebiasaan jajan dengan terjadinya ISPA di TKDharma Wanita Persatuan Sidoklumpuk Sidoarjo.

\begin{tabular}{|c|c|c|c|c|}
\hline \multirow{2}{*}{$\begin{array}{c}\text { Kebiasaan } \\
\text { jajan }\end{array}$} & \multicolumn{3}{|c|}{ Terjadinya ISPA } & \multirow{2}{*}{$\begin{array}{c}\text { Jumla } \\
\text { h } \\
\mathrm{N}(\%)\end{array}$} \\
\hline & $\begin{array}{c}\text { Tidak } \\
\text { pernah } \\
\mathrm{N}(\%) \\
\end{array}$ & $\begin{array}{l}\text { Jarang } \\
\mathrm{N}(\%)\end{array}$ & $\begin{array}{l}\text { Sering } \\
\mathrm{N}(\%)\end{array}$ & \\
\hline Baik & $3(60)$ & $2(40)$ & $0(0)$ & $\begin{array}{c}5 \\
(100)\end{array}$ \\
\hline Cukup & $1(14,3)$ & $3(42,9)$ & $3(42,9)$ & $\begin{array}{c}7 \\
(100)\end{array}$ \\
\hline Kurang & $0(0)$ & $7(50)$ & $7(50)$ & $\begin{array}{c}14 \\
(100 \\
\end{array}$ \\
\hline Jumlah & $4(15,4)$ & $12(46,2)$ & $10(38,5)$ & $\begin{array}{c}26 \\
(100)\end{array}$ \\
\hline
\end{tabular}

Sumber: data primer, 2015

Berdasarkan tabel 2 menunjukkan bahwa dari 26 responden, terdapat 5 responden dengan kebiasaan jajan baik sebagian besar $(60 \%)$ responden tidak pernah terjadi ISPA, dari 7 responden dengan kebiasaan jajan cukup hampir setengah $(42,9 \%)$ responden jarang terjadi ISPA, dari 14 responden dengan kebiasaan jajan kurang setengah (50\%) responden sering terjadi ISPA.

\section{b. Pembahasan}

Hasil Penelitian menunjukkan bahwa ada hubungan jenis kelamin dengan kejadian ISPA. . Karena anak perempuan lebih sering membawa bekal sehingga dan tidak mudah timbul suatu penyakit.

Menurut pendapat Dep. Kes RI (2013)

bahwa salah satu factor resiko yang dapat meningkatkan insiden terjadinya infeksi saluran pernafasan pada anak adalah jenis kelamin laki-laki. Selama masa kanakkanak, laki-laki dan perempuan mempunyai kebutuhan energy serta gizi yang hampir sama.

Berdasarkan hasil penelitian yang telah dilakukan ada hubungan kebiasaan jajan dengan terjadinya ISPA di TK Dharma Wanita Persatuan Sidoklumpuk Sidoarjo. Sering kali anak-anak tertarik dengan jajanan sekolah karena warnanya yang menarik, rasanya yang menggugah selera dan harganya terjangkau masih yang dapat mengganggu kesehatan, baik dalam jangka pendek maupun panjang.Dimana masa ini adalah masa timbulnya suatu penyakit. Jika pola makan dengan perilaku mereka yang 
buruk, maka anak akan mudah terserang penyakit sehingga timbul segala penyakit yang menyertai pada makanan yang dipilihnya.Pencetus penyakit pada anak dapat disebabkan oleh banyak hal, salah satunya adalah kejadian sakit anak dikarenakan mereka mengkonsumsi makanan ringan yang tidak sehat atau menggunakan BTP (bahan tambahan pangan) sehingga membuat tenggorokan menjadi gatal.

Berdasarkan data dan hasil penelitian dan pembahasan yang telah dijabarkan pada bab sebelumnya, maka -siswi sebagian besar berjenis kelamin perempuan dan sebagian besar memiliki kebiasaan jajan yang kurang baik di TK Dharma Wanita Persatuan Sidoklumpuk Sidoarjo. Siswasiswi hampir sebagian jarang terjadinya ISPA di TK DharmaWanita Persatuan Sidoklumpuk Sidoarjo. Ada hubungan antara ISPA di TK Dharma Wanita Persatuan Sidoklumpuk Sidoarjo.

Disarankan orang tua harus memberikan pengertian kepada anak tentang pola jajan yang baik, melakukan pengawasan untuk tidak jajan sembarangan dan membiasakan anak untuk sarapan di rumah. Begitu juga bagi sekolah harus menyediakan jajanan yang sehat di kantin sekolah. Mengupayakan adanya pemberian makanan ringan atau makan siang yang higienis dan bergizi di lingkungan sekolah.

\section{DAFTAR PUSTAKA}

Amourisva, $\quad$ SyafiqAriza. 2014. Kontraindikasi Kebiasaan Jajan Pada Anak Usia Sekolah Dasar. Jurnal Kedokteran Universitas Lampung, Bandar Lampung. Diakses tanggal 01 Januari 2016
Riskesdas. 2013. Riset Kesehatan Dasar, Jakarta, Badan Penelitian dan Pengembangan Kesehatan Kementerian Kesehatan RI. Di aksestanggal 31 Januari 2016.

Nasri, Noor. 2008. Pengantar epidemiologi penyakit menular, cetakan 2. Jakarta:

Dinkes Surabaya. 2014. Profil Dkk Dalam Angka Statistik-10 Penyakit Terbanyak.www.dinkes.surabaya.go.id/ portal/index.php/profil/dkkdalamangka/statistik-10-penyakitterbanyak.com. Diaksestanggal 26 Februari 2016.

Notoatmodjo, Soekidjo. 2009. Pendidikan dan Perilaku Kesehatan, Cetakan 2. Jakarta: PT. RinekaCipta.

Nursalam. 2013. Metodolog iPenelitian Ilmu Keperawatan. Edisi 3. Jakarta: Salemba Medika

Adriani, M. 2012. Pengantar Gizi Masyarakat. Jakarta: Kencana Prenada Media Group.

Fitri, CahyaNing. 2012. Faktor-Faktor Yang Berhubungan Dengan Kebiasaan Mengkonsumsi Makanan Jajanan Pada Siswa Sekolah Dasar Di SDN Rawamangun 01 Pagi Jakarta Timur. Skripsi Kesehatan Masyarakat Universitas Indonesia, Jakarta Timur. Diaksestanggal 10 Februari 2016.

Hidayat, A. A. 2007. Metode Penelitian Kebidanandan Teknik Analisis Data. Jakarta: Salemba Medika.

Kusuma, Kelana Dharma. 2011. Metodologi Penelitian Keperawatan (Pedoman Melaksanakan Dan Menerapkan Hasil Penelitian). Jakarta: CV. Trans Info Media. 